\title{
Mitteilungen
}

\section{Issues in the Dating of Deuteronomy: A Response to Juha Pakkala*}

\author{
By Nathan MacDonald \\ (Theologische Fakultät, Georg-August-Universität Göttingen, Platz der Göttinger Sieben 2, 37073 Göttingen / \\ School of Divinity, University of St Andrews, South Street, St Andrews, KY16 9JU)
}

In his recent essay, »The Date of the Oldest Edition of Deuteronomy «, ZAW 121 (2009), 388-401, Juha Pakkala argues that there are numerous grounds for suspecting that Urdeuteronomium was composed after the fall of Jerusalem in $586 \mathrm{BCE}$. The conventional seventh century date of Deuteronomy that was proposed by de Wette required a coordination of Deuteronomy with the Josianic reformation recorded in II Reg 22-23. Redaction criticism has increasingly revealed the late origin of much of these chapters, and in doing so made the association of Deuteronomy with them much more fragile. Consequently, Pakkala's arguments are timely, though not unprecedented even in recent scholarship. However, his argumentation is more extensive than that offered by others, and commendable for its clarity. Nevertheless, as I shall seek to demonstrate, the arguments offered are problematic. In responding to Pakkala's article, I do not propose to defend an alternative date, but merely to question whether his points establish a post-586 BCE date for Deuteronomy.

Before we approach the specifics of Pakkala's ten arguments, however, we should note a broader set of questions about the methods deployed to date biblical texts. They merit a brief mention, even if they will not be the main focus of my critique. First, can one simply proceed through a via negativa, using omissions as grounds for dating to one period and against dating to another period? Dating of a book like Deuteronomy has usually proceeded by identifying its most conspicuous feature, centralization, and using that to narrow the likely options. Second, how might we date and take sufficient account of Deuteronomy's intention to reconfigure Israelite life? In other words, it seems necessary to recognize that Deuteronomy is not straightforwardly a mirror of its moment of composition. Finally, I wonder at Pakkala's seeming inability to engage the Mosaic presentation of the book with imaginative seriousness. One need not be naïve about the book's attempts to claim authoritative status by projecting later ideas onto a legendary Moses, but it is also a historical datum worthy of reflection that the book matched its literarily constructed shistorical context< so

* This is a revision of a response given to a presentation of Juha Pakkala's arguments about the date of Urdeuteronomium at the meeting of OTSEM in Göttingen in October 2009. I am grateful to Profs. Bernard Levinson, Reinhard Kratz, Hermann Spieckermann and, also, Dr. Pakkala, who encouraged me to publish it. This research was undertaken as part of the Sofja-Kovalevskaja project on early Jewish monotheisms supported by the Alexander von Humboldt Stiftung and the German Federal Ministry of Education and Research. 
well that until modern times none thought to question its Mosaic origins. In other words, it is necessary to credit the authors with the ability to envisage imaginatively a pre-state Israel and for some aspects of the book to reflect that historical imagination.

Let us begin, however, by considering what we can know about the original Urdeuteronomium. For the sake of the argument we will accept Pakkala's preferred reconstruction of Urdeuteronomium, that proposed by the late Timo Veijola. ${ }^{1}$ In my view there are two things that are certain and of decisive importance. First, Pakkala accepts the consensus that Deuteronomy knows and re-interprets the Covenant Code and not vice versa. Thus, a number of the passages that belong to Veijola's Urdeuteronomium are revisions of texts from Ex 20-23..$^{2}$ This is important, for the Covenant Code itself offers a pretty threadbare portrayal of Israelite social structures. Additionally, it offers no instructions about temples, but only a brief attempt to regulate sacrificial practice in Ex 20,24-26. Second, the Urdeuteronomium of Veijola is placed on the lips of Moses, who addresses all Israel in their coming out of Egypt. I agree with Pakkala that if this is all the narrative context provided for the book, it is altogether too slim. Nevertheless, the Mosaic presentation (or Mosaic fiction) of Urdeuteronomium seems to have had a significant bearing on the way it was composed. This Mosaic presentation sets the book in the archaic past prior to the monarchy, with Moses taking the royal position by proclaiming a law that is not only binding, but even of divine origins.

In my view neither of these two observations about the Urdeuteronomium gives any decisive indication one way or the other about whether the document should be dated before or after the fall of Jerusalem. They do, however, eviscerate the significance of the features to which Pakkala appeals as evidence for a post-586 dating of Deuteronomy. In what follows my points refer to Pakkala's numbered arguments.

First, we should not be surprised by the absence of the monarch in the law code itself. In Hammurabi's lawcode it is Hammurabi's subjects that come under the law, not the monarch himself. Consequently of the approximately two hundred and fifty laws in Hammurabi's lawcode that are fully extant, less than five percent refer to the king or royal trappings. This highlights how remarkable Deuteronomy's law of the king is $(17,14-20)$, but as Pakkala observes this is not part of Veijola's Urdeuteronomium, and falls outside our discussion. In addition, Moses' replacement of the king as the promulgator of the law is ingredient to the imaginative pre-monarchical literary context.

Second, Pakkala is unfortunately somewhat vague about the lack of evidence of state infrastructure and organization. What absence might we expect to have been made good were Urdeuteronomium composed in the monarchic period? Nevertheless, in response we might observe that the lack of state infrastructure reflects both Urdeuteronomium's reliance on the Covenant Code, where these things are also absent, and the Mosaic presentation. These are sufficient grounds for the absence of references to state infrastructure, with no appeal to composition after $586 \mathrm{BCE}$ required. Indeed, were it not for the Mosaic presentation it is difficult to see why state structures should be absent. If Urdeuteronomium were composed in the sixth century BCE, there is no reason for these to be absent since the hope

1 Pakkala's choice of Veijola's reconstruction of Urdeuteronomium as set out in his ATD commentary is somewhat problematic, since Veijola's untimely death means that his analysis is truncated and runs only as far as Dtn 16 (T. Veijola, Das fünfte Buch Mose: Kapitel 1,1-16,17, ATD 8/1, 2004). Consequently, for some chapters it is difficult to »debate the details of argumentation « (Pakkala, Date, 388), since they do not exist.

2 The standard account of this is B. Levinson, Deuteronomy and the Hermeneutics of Legal Innovation, 1998. 
of a full restoration persisted, whether focused around Jehoiachin, Shealtiel or Zerubbabel. Into the fifth century, the nascent Yehud community had some societal structures necessary for its own good organization within the Persian administration: some form of centralized local leadership, ability to raise revenue, and some way of administrating communal justice. Of course, Pakkala may object that this is not the same thing as state infrastructure - but if so, he needs to be less vague about what this means.

Third, the Mosaic presentation also explains the appearance of 'Israel and the absence of Judah in Urdeuteronomium. The term sIsraek would appear to have been appropriated by Judahites at least by the time of the composition of Ezekiel and Deutero-Isaiah. We might well suspect that this appropriation first took place towards the end of the Judahite monarchy and that it was politically expedient to do so. In other words, it may have allowed late Judahite kings to claim sovereignty over the former territory of the northern kingdom.

Fourth and fifth, the Covenant Code is similarly concerned with sacrifice rather than temple, as we have already observed. Urdeuteronomium's use of māqôm also reflects its legal predecessor, and Urdeuteronomium's distinctive appropriation of the term is central to what Levinson characterizes as its hermeneutics of legal innovation. The avoidance of explicit references to Jerusalem reflects the Mosaic presentation. Implicit references to the temple site are found in Pentateuchal materials besides Deuteronomy (e.g. Gen 14;22) and give no secure ground for dating. Such implicit referencing points to the biblical writers' ability to speak in subtle ways about realities which are in the future from the perspective of the literary plot. ${ }^{3}$

Sixth, the references to Israel's tribes are consonant with the Mosaic presentation. Pakkala's reference to the lateness of the stwelve tribes< is not entirely relevant, for Urdeuteronomium uses šebæt only as a societal unit, and not necessarily with reference to the later canonical twelve tribes.

Seventh, the use of yiqtol forms is entirely appropriate given the Mosaic presentation. The yiqtol form, of course, also reflects Urdeuteronomium's appropriation of the Covenant Code in Ex 20,24-26, which employs the yiqtol and weqatal forms.

Eighth, the presence of a name theology in Urdeuteronomium turns upon whether or not one accepts that 12,21a ab belongs to Urdeuteronomium or not. Veijola's attribution of this to Urdeuteronomium is not broadly accepted, since most scholars have sought the original instructions about centralization in 12,13-19. Veijola's sole justification for this position is by appeal to Levinson who argued that v. 21 is an interpretation of the altar law in Ex 20,24-26. ${ }^{4}$ According to Veijola interpretation of the Covenant Code only occurs in Urdeuteronomium and not in subsequent redactions. We should note, however, that Veijola's appeal to Levinson is rather inconsistent. In particular, Levinson argues that v. 15 with its use of tizbah, $b^{e} r \bar{a} k \bar{a} h$ and $b^{e} k o l$ is also a re-interpretation of the Covenant Code's altar law. ${ }^{5}$ But

3 Pakkala's argument at this point would suggest that not only is Urdeuteronomium post-586 but that the building of the temple in 515 BCE (or mid- $5^{\text {th }}$ century, with D. Edelman, The Origins of the second Temple: Persian Imperial Policy and the Rebuilding of Jerusalem, 2005) marks a terminus ad quem. Yet it is precisely at these points that hopes of a dynastic restoration remained strong - if not, perhaps, universal, depending on how one construes Deutero-Isaiah's use of royal language - and so it is unclear why Urdeuteronomium lacks any attempt to realize a state infrastructure as per the second argument.

4 Veijola, Das fünfte Buch Mose, 269.

5 Levinson, Deuteronomy, 35. 
Veijola excluded v. 15 from Urdeuteronomium as a later addition, ${ }^{6}$ in the process nullifying his own argument that allusion to the Covenant Code does not occur in the later redaction of Dtn 12.

There are good grounds for thinking that Veijola's attribution of $12.21 \mathrm{a} \propto \mathrm{b}$ to Urdeuteronomium is not compelling within the terms of his own logic. With most scholars Veijola holds that vv. 15 and 21 are related to one another and are mutually exclusive. In v. 15 you can have profane slaughter everywhere including in towns near to the sanctuary, but in $\mathrm{v}$. 21 you can only have profane slaughter at some distance from the sanctuary. Both verses fit relatively loosely to their context in Urdeuteronomium and so either verse might be a candidate for excision. However, two considerations would suggest the priority of v. 15. First, if we consider the words that each verse has in common with the altar law in the Covenant Code, only $b^{e} r \bar{a} k \bar{a} h$ does not find a parallel elsewhere in Urdeuteronomium's altar law. In other words, v. 21 could be a reinterpretation of Urdeuteronomium alone, but this is not the case for v. 15. Second, it is easier to assume the permissiveness of v. 15 ('any of your towns<) was explained in v. 21 to apply only to distant cities through the justification the place is too far away<, even though this led to a narrowing down of the towns to which v. 15 applies. The alternative requires that the restrictiveness of v. 21 was ignored, but if so we might then expect some secondary justification to explain this reinterpretation, for it now creates a problem for the attentive reader.

Whatever one makes of these verses, the suggestion that Urdeuteronomium subscribes to a name theology dangles by an extraordinarily thin thread. This is not even to venture into the difficult question of whether the name in Deuteronomy is really best understood as a form of hypostatic presence.

Ninth, we should begin by observing that Pakkala introduces a shift in the argumentation. In all the other points his paper makes arguments internal to Urdeuteronomium, following the lead of earlier scholars. There is wisdom to this approach, for the case of Elephantine raises more questions than it answers. Let me pose just a few. First, what was the history of this community (i.e. where and when did it originate) and, thus, what might this say about any authoritative writings that may have been known there? What authority did those writings have, after all the clearest locus of canonical authority in Elephantine seems to be the Jerusalem leadership? How might a diverse set of written traditions be resolved in this community? Would temples be understood as permissible, provided they were outside the land of Israel? After all, even a writer like Malachi, who is widely agreed to be strongly influenced by Deuteronomistic thought, can speak of acceptable sacrifices to YHWH in other places $(1,11)$.

Tenth, it is not clear to me that for Deuteronomy the choice lies with either idealistic or practical; Pakkala's either-or is a false alternative. The ancient writers seem quite capable of thinking about the past by means of analogy, neither simply projecting the present onto the past nor offering an unrealizable ideal. This means that the past is not transparent to the present; the past makes claim upon the present, but not in any straightforward manner. Within the Old Testament one of the clearest examples of what I mean would be the priestly Tabernacle. The description of the Tabernacle and the assembled tribes in the Sinai pericope is clearly meant to have authoritative force for the Yehud community, but not in any literalistic manner. That is, the Tabernacle and ordered camp of Ex 25-40 and Num 1-10 are not realizable in a straightforward way. Similarly in the Deuteronomic-Deuteronomistic literature, I would argue that the same issues confront us with the hecrem legislation of Dtn 7 ,

6 Veijola, Das fünfte Buch Mose, 273. 
which could not be enacted literally on any >Canaanites Deuteronomy's program are no decisive evidence for its time of composition.

Scottish law, much maligned recently due to events surrounding the release of Abdelbaset Ali al-Megrahi, has a novelty such that a jury can return three possible verdicts: guilty, not guilty and not proven. Has Dr. Pakkala shown that Urdeuteronomium must have originated after the fall of Jerusalem? We must conclude that the case is not proven.

In a recent article in this journal Juha Pakkala offered several reasons to date the oldest edition of Deuteronomy after 586 BCE. This response examines the reasons offered and finds them problematic.

Dans une étude récente publiée dans cette revue, Juha Pakkala a avancé un certain nombre de raisons pour date la plus ancienne édition du Deutéronome après 586 av. n. è. Cet article analyse les arguments évoqués et les juge problématiques.

In seinem kürzlich in dieser Zeitschrift veröffentlichten Aufsatz hat Juha Pakkala verschiedene Gründe dafür angegeben, dass die älteste Fassung des Deuteronomiums nach 586 entstanden sein muss. In diesem Beitrag werden seine Begründungen überprüft und für problematisch befunden. 